\title{
The vulnerability of the aquifer units in the flood-affected areas of the east coast Peninsula Malaysia
}

\author{
John Stephen Kayode ${ }^{1} \cdot$ Mohd Hariri Arifin ${ }^{1,2} \cdot$ Mohd Khairul Amri Kamarudin $^{3} \cdot$ Azimah Hussin $^{2}$. \\ Mohd Nawawi Mohd Nordin ${ }^{1}$. Norsyafina Roslan ${ }^{2}$
}

Received: 4 September 2017 / Accepted: 1 February 2019 / Published online: 19 February 2019

(C) The Author(s) 2019

\begin{abstract}
During the periods of strong winter monsoon, the occurrence of extensive floods in the low-lying areas mostly in the east coast part of the Peninsula Malaysia continually results in huge destruction to public and private utilities, damage to farmlands, and in addition, leads to loss of lives with outbreak of epidemic which prompted evacuations of hundreds of thousands from their homes and communities. This paper presents research results on the impacts of subsurface water on the east coast Peninsula Malaysian floods, therefore complementing the existing data on the flooding events in this area. In our finding, we present the vulnerability of the aquifer units in the flood-affected communities to floods during intense precipitations and then proffer suggestions to prevent near future occurrence. The partial coverage of the alteration zone that is completely nonexistent in this area should have provided the needed essential storage and transmissivity if present in the east coast Peninsula Malaysia environments. Most of the aquifer units in this part are unconfined and are opened to surface water. We applied electrical resistivity tomography methods of geophysical prospecting and borehole lithologic logs to study the subsurface structures prone to flooding in addition to the information on the rainfall data. However, the GOD vulnerability Index rating method was modified and improved upon with the additions of fluctuations of borehole water heights FBWH and the river bank heights RBH together with the topography parameters to produce the GOD-FBRT Index that better refine the method by considering the literal movement of fluids within the subsurface. The configuration of the Kelantan River basin land system as delineated by this study makes the entire east coast areas vulnerable to flooding with the degree of vulnerability as computed in the study area that ranged between 0.1 (very low) and 1.0 (very high).
\end{abstract}

Keywords Weathered/fractured bedrocks $\cdot$ Surface-subsurface water transmissivity $\cdot$ Floods $\cdot$ GOD-FBRT index $\cdot$ Vulnerability

\section{Introduction}

The east coast Peninsula Malaysian states received highintensity rainfall particularly in the months of November to

Editorial handling: Dikun Yang

John Stephen Kayode

jskayode@gmail.com

1 School of Physics, Geophysics Unit, Universiti Sains Malaysia, 11800 USM, Penang, Pulau Pinang, Malaysia

2 Department of Geology, Universiti Kebangsaan Malaysia School of Environmental Science and Natural Resources, 43600 UKM, Bangi, Selangor, Malaysia

3 East Coast Environmental Research Institute (ESERI), Universiti Sultan Zainal Abidin, Gong Badak Campus, 21300 Kuala Terengganu, Terengganu, Malaysia
January during which the area recorded the maximum precipitations brought about by the monsoon rains. The summer monsoon which is commonly called "southwest monsoon" and the winter monsoon also known as the "northeast monsoon," with the former, usually begin towards the end of May and end towards late September, while the later starts from the month of November through to the third month of the following year. Peninsula Malaysia experienced a significant amount of precipitation all year round with the maximum amount during the northeast monsoon period. Even with the peculiar nature of the Peninsula, the monsoon rainfall in this part of the South-eastern Asian country still experiences a major unpredictability of inter-annual time scale precipitations which relates the floods in this area to an anomalously intense monsoon seasons and drought (Tangang et al. 2008; Tangang et al. 2011). The Malaysian climate is dominated by the South-eastern Asian monsoon system with a cycle of two 
contrary winds, i.e., the southwest monsoon and the northeast monsoon. During these periods of intense winter monsoon, the occurrence of widespread floods in low-lying areas mostly in the east coast part of the country repeatedly results in huge destruction to public and private utilities. Damages to farmlands and loss of lives with the outbreak of epidemic which prompted the evacuation of hundreds of thousands from their homes and communities also characterized this activity. Accordingly, this magnitude of destruction and the need for accurate and useful subsurface characterization are imperative. Hence, this study focused on the main suggestions that can prevent the nearest future occurrence. The good forecast of seasonal changes in climatic conditions with studies like this provides valuable information for decision-makers to manage better resources, establish mitigation plans, and enhance response strategies related to floods.

An existing problem in this part of the country is the lack of proper knowledge about the relationship between surface water discharge and the susceptibility of subsurface structures about the surface and groundwater interaction and inflow during intense rains. Consequently, the Government was impelled to put some structures in place whereby future occurrence of these catastrophic events could be adequately managed through the provision of monitoring boreholes and then set in position suitable program for remediation. Therefore, the main objective of this study is to apply a rapid and efficient geophysical method to delineate the subsurface water-bearing units in the study area intending to determine its vulnerability to the massive volume of surface water during intense precipitations that ultimately pave the way to flooding. As part of the objectives is to understand the causes of flooding in the area and propose corrective measures for future planning, the vulnerability is a notion frequently applied to depict a household's situation comparative to poverty and economic stress (Pelling 1997). On the other hand, this work provides a wider view that extends the term to geophysical perspective, as applied to subsurface geological sources, in this case, its suitability in reducing the likelihood of an area being flooded.

Despite the fact that electrical resistivity methods have widely been used to delineate severe flood-prone zones with the availability of some of the reports (i.e., Baksi et al. 1987; Bayley 1995; Benson et al. 1997; Altinakar et al. 2008; Dahan et al. 2008; Juneng and Tangang 2008; Meyer et al. 2009; Juneng et al. 2010; Salimun et al. 2010; Feng and Wang 2011; Dawod et al. 2012; Giustarini et al. 2013; Park et al. 2013; Tehrany et al. 2014) and many others that were available for this study, exposure to subsurface water-bearing structures through feeble overburden in a fractured/weathered basement environment cannot be overemphasized. Although surface geophysical methods are continuously being applied in a variety of ways, it is very necessary to study the detailed subsurface water-bearing geological structures which play a fundamental role in the control of massive surface water movements during intense floods through the application of active geophysical methods as part of flood fortification towards flood risk management. It is in this wise that our approach is crucial to the joint efforts of Malaysian Meteorological Department and the Department of Irrigation and Drainage to safeguard infrastructural and key resource sectors that require protective actions. This is to prepare for, or with the purpose of mitigating against vastly dynamic catastrophic floods that usually cause significant loss-of-life, a health hazard and risks, damaged to properties and economic losses in east coast areas of the Peninsula Malaysia. To protect the people residing in these areas, the public and private properties and the valuable environments from the destructions and disorderliness that always characterized flooding, Government took the initiative to support this study.

In view of the incredible and irreversible potential damages to health and infrastructural facilities, such as agriculture, transportation, bridges, and even the irreparable human fatalities, flood control and prevention measures are urgently required in the east coast Peninsula Malaysia as early warnings and emergency responses to floods are of great importance (Allison and Hobbs 2004; Feng and Wang 2011). To minimize these, it is imperative that governments and her agencies take preventive measures.

This paper thus contributes to the process of assessing the condition of the subsurface water-bearing geological structural units and their interconnectivity to surface water during intense precipitations. As a complement to the geological observations, some electrical resistivity tomography measurements were acquired in the study area to image the possible presence of geological heterogeneities in the subsurface that could be saturated with water. Several geophysical crosssections were obtained by using pole-dipole electrode configurations with a maximum of 200-m survey length. The GOD vulnerability Index rating method was modified and improved upon as part of the major contributions, the additions of fluctuations of the borehole water heights FBWH, and the river bank heights RBH together with the topography parameters of the area helped to produce the GOD-FBRT Index that better refine the method. This was achieved by considering the literal movement of the fluids within the subsurface structural units.

\section{The study area, geology, hydrology, and geomorphology}

The study was conducted in the worst affected areas by the December 2014 to early January 2015 Monsoon floods which hit states of the east coast Malaysia. The states are Kelantan, Pahang, and Terengganu. This study covered the basins of Rivers Kuantan and Kelantan (Fig. 1). The Kuantan River and its tributaries drained some of the areas mostly responsible for the incessant floods been experienced time and again in this part of 


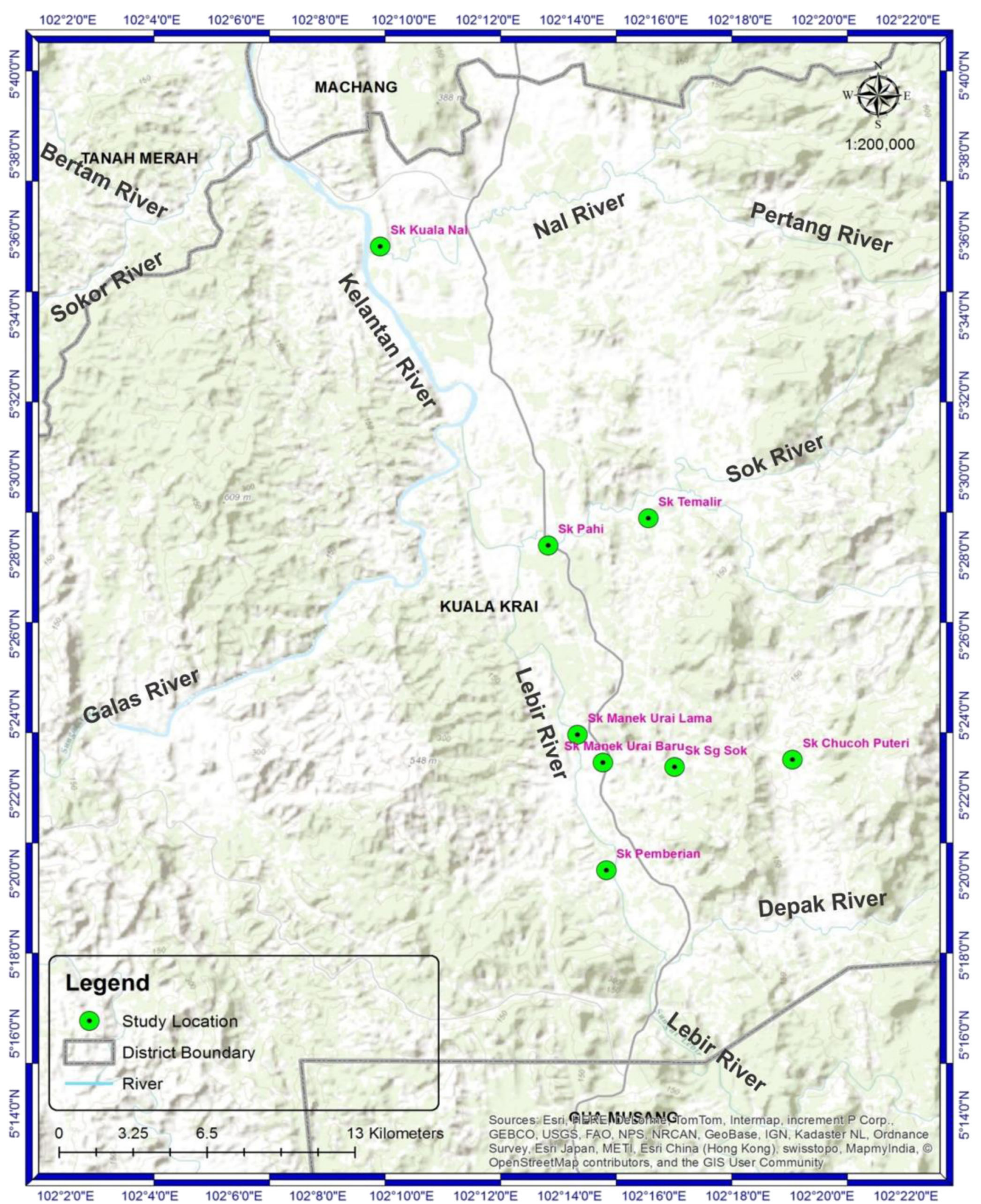

Fig. 1 Topographic map of the study area showing the major rivers

the country. The Kelantan River basin situated in the study area between latitudes $4^{\circ} 40^{\prime}$ and $6^{\circ} 12^{\prime}$ north and longitudes $101^{\circ} 20^{\prime}$ and $102^{\circ} 20^{\prime}$ east with a maximum extent of about $150 \mathrm{~km}$ by $140 \mathrm{~km}$. The length of River Kelantan is about $250 \mathrm{~km}$ and the 
total area drained is about $13,000 \mathrm{~km}$ that is about $90 \%$ of the total area. This river splits into two, i.e., the Rivers Galas and Lebir, respectively, near Kuala Krai, at a distance of about $100 \mathrm{~km}$ from the river mouth. River Galas is formed by the intersection of the Rivers Nenggeriri and Pasir, whereas River Nenggeriri takes its course from the south-western part of the central mountain, and River Lebir also flows from the Tahan Mountain. The Kelantan River system flows northward and passes through the major towns in the area such as Kota Bharu, Tanah Merah, Pasir Mas, and Kuala Krai before it ultimately emptied its contents into the South China Sea. A proportion of about $90 \%$ of this area is steep mountainous country going up to about $2150 \mathrm{~m}$ heights with the undulating land covering the remaining 10\%. Tropical rainforest encloses the enormous hilly areas amid palm plantations; rubber plantations and some paddy rice are cultivated in the lowland area. Granitic soil that comprises a mixture of fine to coarse sand and clayey materials has underlain the east and western portions of this area. This area has an annual precipitation of about $2500 \mathrm{~mm}$, a large amount of which occurs during the North-East Monsoon rains between October and January of every year. The mean annual temperature as measured at the meteorological center located at Kota Bharu is about $27.5{ }^{\circ} \mathrm{C}$ with mean relative humidity above about $90 \%$. The average flow of the Kelantan River measured at Guillemard Bridge is about $557.5 \mathrm{~m}^{3} / \mathrm{s}$ (Ibbitt et al. 2002; Tangang et al. 2008; Tangang et al. 2011; Varikoden et al. 2011; MMD 2015).

Geologically, the area is underlain by Permian formations which consist mainly of Phyllite, slate, and shale with sandstone and schist as subordinates as shown in Fig. 2. Schist, intermediate to mafic volcanic rocks, comprises mainly pyroclastics. Triassic interbedded sandstone, siltstone and shale, and Cambrian rock intrusion units. The northern part is mostly underlain by Quaternary rocks such as sand, clay, silt peat with some gravel intercalations (Alexander 1968; Khoo and Tan 1983; Richardson 2013). The geological setting of the present study area showed subsurface lithological sequence composed of the Schist; Permian, Triassic, and Cambrian rock units successively underlain the area. The Permian rock unit underlain the Schist and also overlain the Triassic unit and jointly occupied the major parts of the western region that stretched to the central part. Nevertheless, some minor intrusions of the Cambrian unit were noticed in the southern part. On the other hand, the Cambrian rock unit formed the major rock units in the eastern section of the study area, and some intrusions of the Permian rock unit noticed along the southern part of the area. Different granitic rock units were said to have made up of the Permian rock unit as reported in Khoo (1980). Rivers Galas and Kelantan are the two main rivers that drained the study area. River Galas is the longest and the biggest river with its tributaries flow northward to link River Kelantan, which also flows in the northward direction to the South China Sea. River Lebir is smaller than River Galas. However, it forms the main tributary of it.

\section{Methodology}

Several geophysical field surveys were conducted in the selected areas due to the high degree of spatial heterogeneity of the subsurface structures in the study area. Our study involves a qualitative approach to using ERT method that employs an artificial source of current I, injected into the subsurface through point electrodes and the resulting potential difference $\mathrm{V}$, dropped across these electrodes was measured at other electrode positions in the neighborhood of the current flow.

ABEM SAS 4000 Terrameter imaging system together with the ES10-64C selector, combined with two-reel of $200 \mathrm{~m}$ cables, a $30 \mathrm{Ah}$ dc battery, and 41 pieces of stainless steel electrodes positioned at a space of $2.5,3.0$, and $5.0 \mathrm{~m}$ spacing, were used to acquire the $2 \mathrm{D}$ resistivity data (Fig. 3 ) as space constraint was a factor in the selection of inter-electrode spacing. The acquired data was quantitatively modeled by an iterative modeling process using RES2DINV software (Loke et al. 2006; Loke 2014).

Majority of the issues encountered in all the ERT models generated from a surface metal electrode placement is the constancy reduction in the data resolutions exponentially with depths. Limitations emerged because of the awkwardness in reliably quantifying the images obtained. Ambiguities due to source-receiver separation as a result of electrode misplacement contribute to the data error using ERT (Oldenborger et al. 2005; Fernández-Martínez et al. 2017).

To obtain higher-resolution images that are consistent while acquiring ERT data with multielectrode cable system using fixed interelectrode spacing, the pole-dipole configurations were selected to capture optimum anomaly data with reasonable depth coverage that gives high signal to noise ratio using the combined forward and reverse measurements. A wide-ranging dataset of electrode configurations with extremely low noise is crucial in acquiring high-resolution ERT images. The sensitivity of the selected electrode configurations was able to capture variations in the potentials because of the changes in the subsurface lithological units. The dipole-dipole array was circumvented due to its low signal to noise strength. Unlike the pole-pole array, the effect of remote electrode $\mathrm{C} 2$ is far less in the pole-dipole array when it is placed at a distance large enough, i.e., $>5$ times the distance between $\mathrm{C} 1$ and P1.

Though the surface topography effect on the ERT data which could result in non-uniformity visualization of the model geometries produced and resulted in the subjective of the lithological layer inverse modeling. However, FernándezMartínez et al. (2017) suggested the choice of advanced 3D geomodeling and semi-automatic mesh generators. But the RES2DINV software used in this study already incorporated the later in its algorithm which accounted for the surface point observations for the analysis and interpretations of the inversion results (Oldenborger et al. 2005; Chambers et al. 2006; Williams and Scheib 2008; Malehmir et al. 2016). 


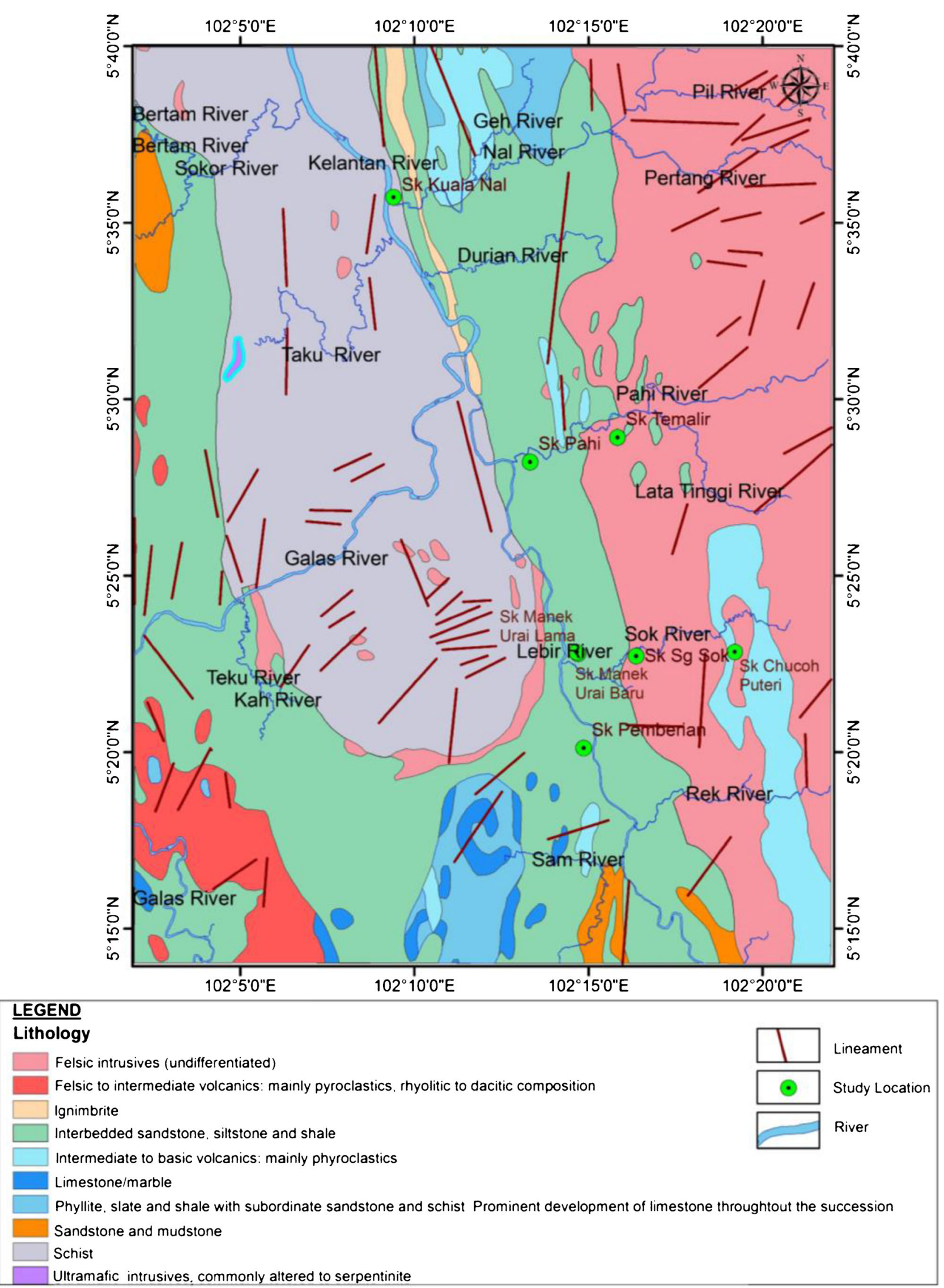

Fig. 2 Geological map of the study area showing the study locations, major lineaments, and the major Rivers 
Fig. 3 ABEM SAS 4000 Terrameter imaging system for the 2-D ERT data acquisition showing the sequence of measurements to build-up a pseudosection (after Loke 2014)

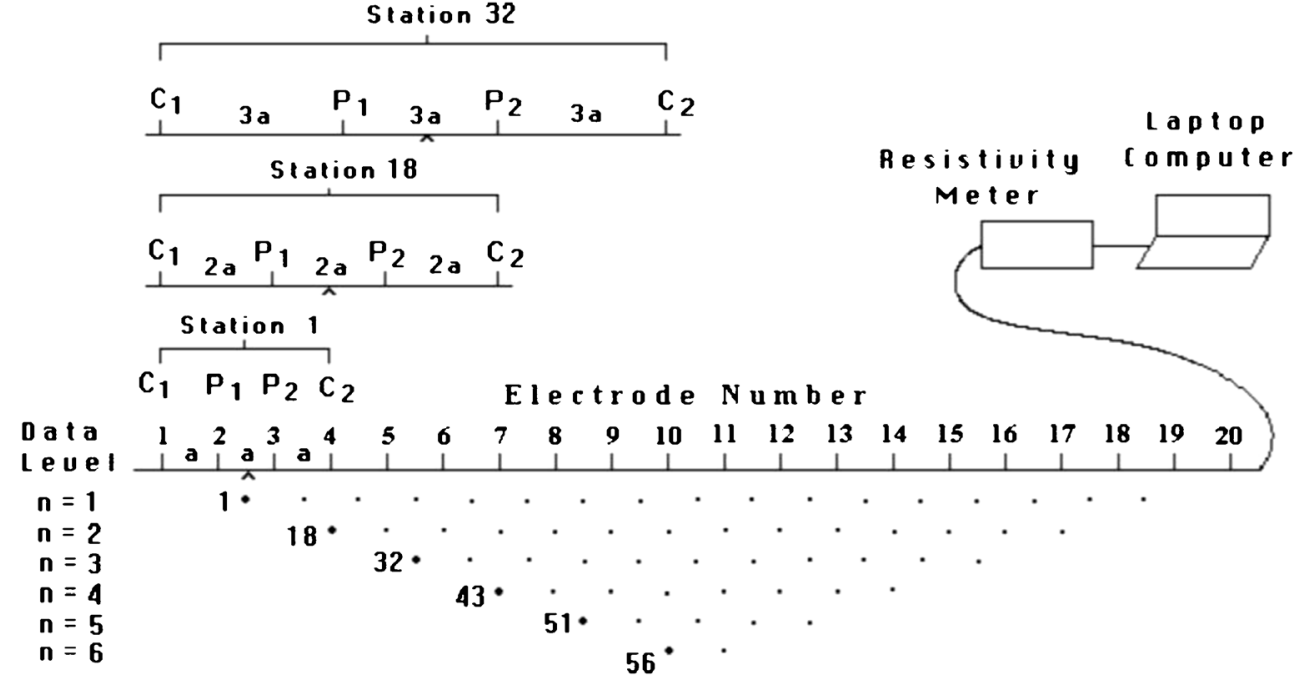

Many papers have been published on the subject vulnerability of aquifers in varieties of ways. Most of these works were based on the extent of pollutants or contaminants in the subsurface that are statistically analyzed using ranking systems. Many rating methods have been proposed and implemented, e.g., Foster (1987), devised a ranking system that uses the groundwater occurrence, overall aquifer, and depth to the water table mostly referred to as the GOD-Index criteria for classifying these parameters. On the other hand, Aller et al. (1987) developed their ranking system based on the seven parameters that were termed DRASTIC which many researchers (i.e., Bai et al. 2012) have found useful by modifying it to suit their need as in SINTACS (Civita and De Maio 1997). In more recent studies, Wolters et al. (2014) applied a common index model incorporated to Fuzzy logic to study urban groundwater vulnerability, whereas FernándezMartínez et al. (2017) applied the four methods (i.e., the GOD, SI, DRASTIC, and SINTACS) to study nitrate pollutant with a convincing statement that the susceptibility index, SI method showed some realistic in delineating groundwater protective parameters. With careful consideration of the situation surrounding our study area, the GOD index was adopted and modified as GOD-FBR to suit the scenario of this work.

\section{Results and discussion}

\section{The relationship between the flow within aquifers and the fluctuation of riverbank heights in the study area during flooding}

Information on the rainfall data was obtained from the Malaysian Department of Irrigation and Drainage during the flooding period of December 2013 and January 2014 covering the days the ERT data acquisition was conducted. The peculiarity conditions of the East Coast Peninsula Malaysia, fluctuations of borehole water heights (FBWH), and riverbank heights $(\mathrm{RBH})$ were considered along with the ERT measurements in the determination of the aquifer vulnerability in the area. The research was focused on interconnectivity between the surface water and the groundwater during intense precipitations.

The data for the fluctuation of riverbank heights $(\mathrm{RBH})$ were combined with the fluctuation of the boreholes water heights (FBWH) and the measurements through ERT to generate Fig. 4. Information made available from the Department of Irrigation and Drainage showed that data were consistently recorded for many decades (i.e., between 27 and 41 years) in all the 16 locations accessed in the study area with minimal errors. In our scenario, we are proposing a new method of GOD known as the GOD-FBR Index to better refine the method. Since Foster (1987), GOD method does not take the literal movement of fluids within the subsurface into consideration; this study hence, modified the method to account for the fluctuations of riverbank heights $(\mathrm{RBH})$ combined with the fluctuations of the borehole water heights (FBWH) as delineated. The shallow groundwater level implies a high groundwater vulnerability over the area. Following the original rating scheme of the scores of this parameter that ranged from 7 to 10 by Aller et al. (1987), this study tends to predict the factors that govern the aquifer vulnerability in east coast Peninsula Malaysia.

\section{The electrical resistivity tomography}

Electrical resistivity tomography is also known as electrical ground imaging (EGI) that is a geophysical sophisticated method usually applied to verify the subsurface resistivity distribution in the course of ground surface measurements (Reynolds 1997). The ground geophysical investigations into the subsurface structures on the east coast Peninsula Malaysia incorporated surface geophysical investigations using 

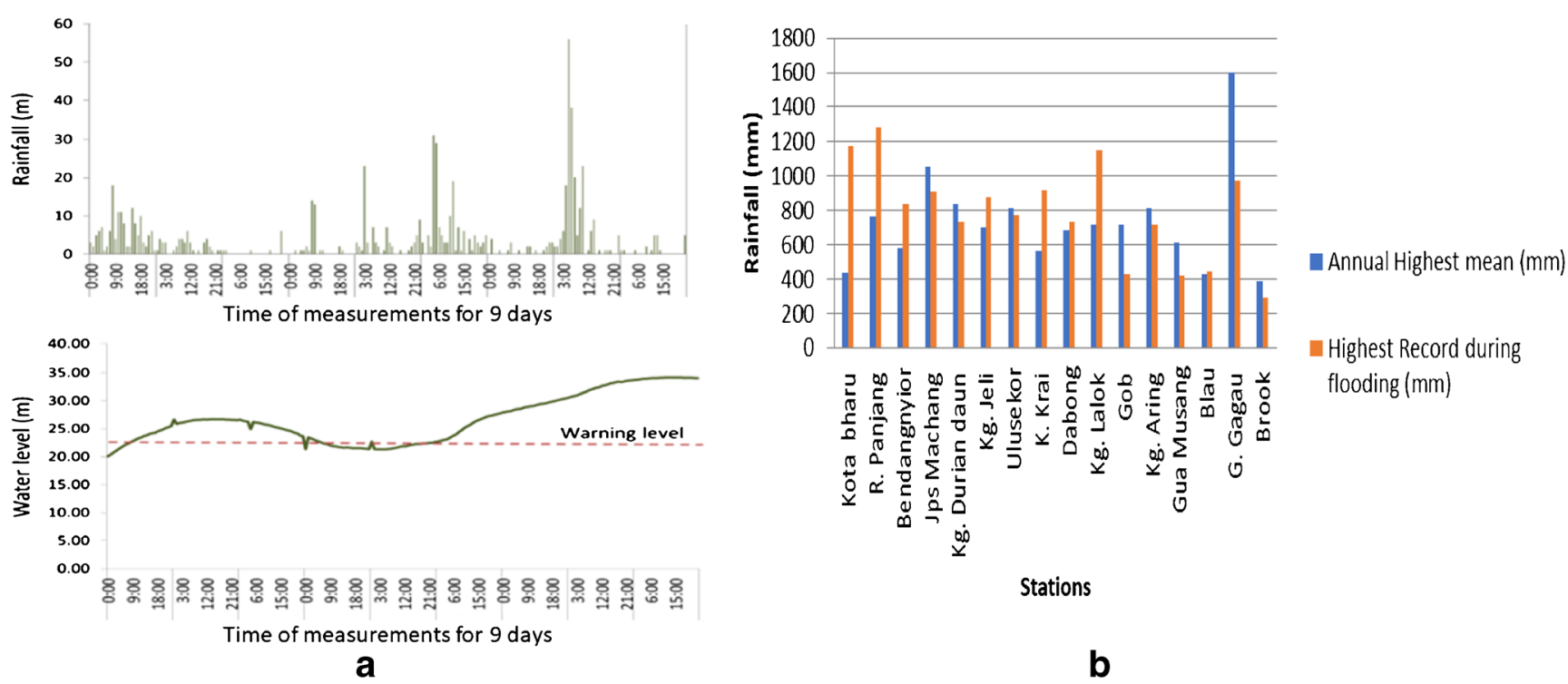

Fig. 4 A typical rainfall measurements and water levels at the stations. a Average annual maximum rainfall and highest rainfall during flooding recorded within the Kelantan River Basin obtained from the Malaysian Department of Irrigation and Drainage

electrical resistivity tomography (ERT) method. This approach has been proved to be brisk for the determination of subsurface variations in electrical resistivity which is correlated with the changes in the clay contents, water saturation, porosity, and the concentration of dissolved conductive fluids in the regolith and bedrock (Loke et al. 2006).

The common problems in all the ERT models generated from a surface metal electrode deployment are the diminutions in resolutions exponentially with depths. It is, therefore, necessary to strengthen the interpretation of such models with appropriate ground-truth in concurrence with borehole data.

The results obtained from the analysis of observed electrical resistivity field data with the pole-dipole configuration were presented in profiles $1-8$ after the application of $2 \mathrm{D}$ resistivity inversion to obtain the geoelectric parameters, i.e., depth to the bedrock and resistivity values, and thicknesses of the regoliths in this area (Figs. 5, 6, 7, 8, 9, 10, 11, and 12). Most parts of the area studied have very thin topsoil, i.e., between 3 and $16 \mathrm{~m}$ thickness (Fig. 13), and minimal resistivity values ranging between $75 \Omega-\mathrm{m}$ and $1000 \Omega$-m, i.e., profiles $1-3$ and $6-8$. About $75 \%$ of these areas which are characteristics of Permian formations predominantly consist of Phyllites, slate, and shale amid sandstone and schist as subordinates are unwrapped to subsurface groundwater with very thin regolith envelope make the subsurface structures susceptible to inflow of surface water during intense precipitation, and hence highly vulnerable to flooding as shown in Fig. 4. The low resistivity and thin topsoil bed sections in most of the areas surveyed are attributed to the vulnerability of very shallow weathering profiles in the east coast Peninsula Malaysia, particularly the Kelantan River Basin to incessant floods every year.
The areas are underlain by granitic soil which comprises a blended fine to coarse sand, and clayey weathered materials were delineated as areas covered with relatively thick topsoil with thicknesses of about between 10 and $16 \mathrm{~m}$. High resistivity values for the weathered zones were delineated between $1000 \Omega$-m and $15,000 \Omega$-m, i.e., along profiles 4 and 5 , (Figs. 9 and 10) which are consistent with the sandstone, siltstone, and shale of Triassic formations and Cambrian rock intrusion units as shown on the geology map (Fig. 2). The depths of the weathering in these formations are consistent across the structural sequence between the more resistive Cambrian rocks intrusion units and the Triassic formations. The diverse in weathering profiles of the subsurface structures as witnessed on the east coast Peninsula Malaysia is evidently shown and cut across all the rock formations in this area by the borehole logs, water levels, and hydrograph, and the 2D inversion ERT models which reflect the changes from one rock unit to another with distinct variations in the resistivity values delineated as well as the water level heights.

The inconsistency in the weathered bedrock in this area allows the delineation of low resistivity values that increase between about $2 \Omega-\mathrm{m}$ and $1000 \Omega-\mathrm{m}$ as shown in the profiles of Figs. 5, 6, 7, 8, 9, 10, 11, and 12, and depths greater than $80 \mathrm{~m}$ were delineated along profile 8 . Granitic boulders and weathered rocks were delineated as high resistivity zones with values that ranged from about $600 \Omega-\mathrm{m}$ to about $30,000 \Omega-\mathrm{m}$. The granitic boulders gave the highest resistivity values while the weathered materials have moderately low to high resistivity values as obtained from the ERT interpretations.

Figure 5, along with profile 1, shows the 2-D ERT Inversion plot with the position of the borehole together with the interpreted lithologic subsurface structural units. The 


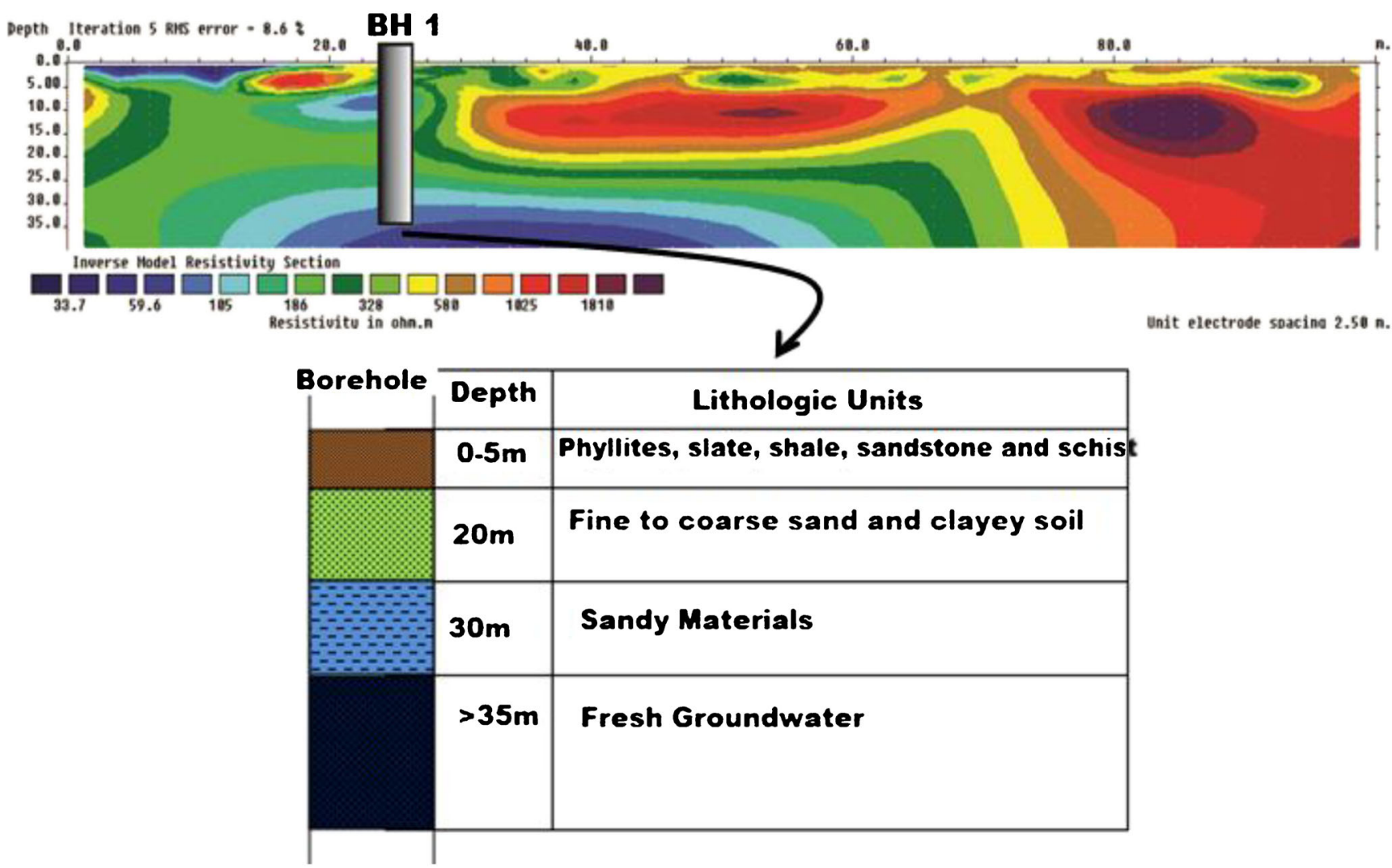

Fig. 5 2D electrical resistivity tomography inversion model of the study area along profile 1 showing the location of borehole 1 at $25 \mathrm{~m}$

phyllites, slate, shale, sandstone, and schist characterized the topsoil. Fine to coarse sand with clayey intercalations form an interface between the sandy materials and their corresponding depths. Granitic bedrock was delineated at a depth of approximately $10 \mathrm{~m}$ around $80 \mathrm{~m}$ from the starting point (i.e., the first electrodeposition).

The interpreted subsurface geological units from the 2D resistivity inversion and lithologic units are as shown in Fig. 6,

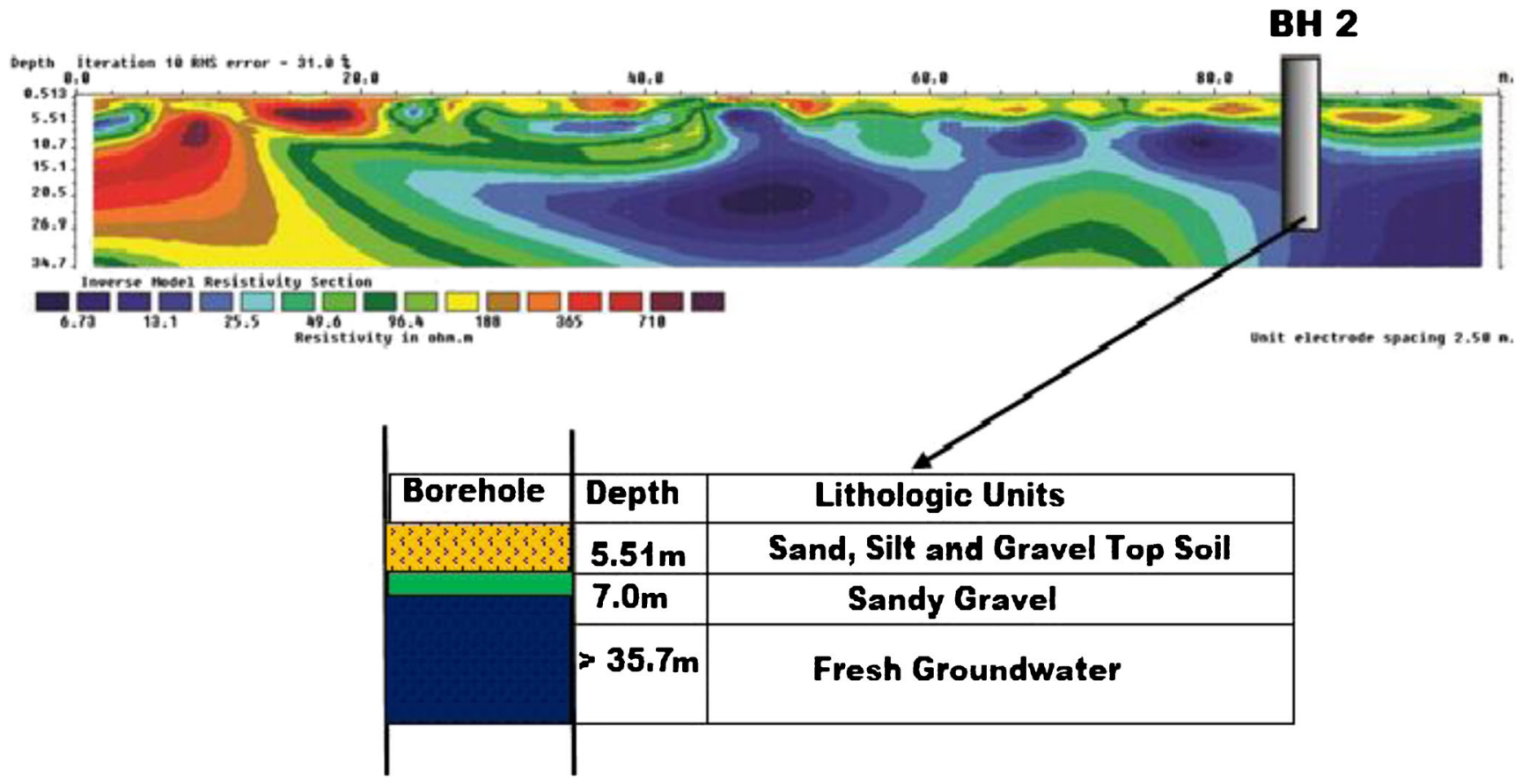

Fig. 6 2D electrical resistivity tomography inversion model of the study area along profile 2 showing the location of borehole 2 at $80 \mathrm{~m}$ 


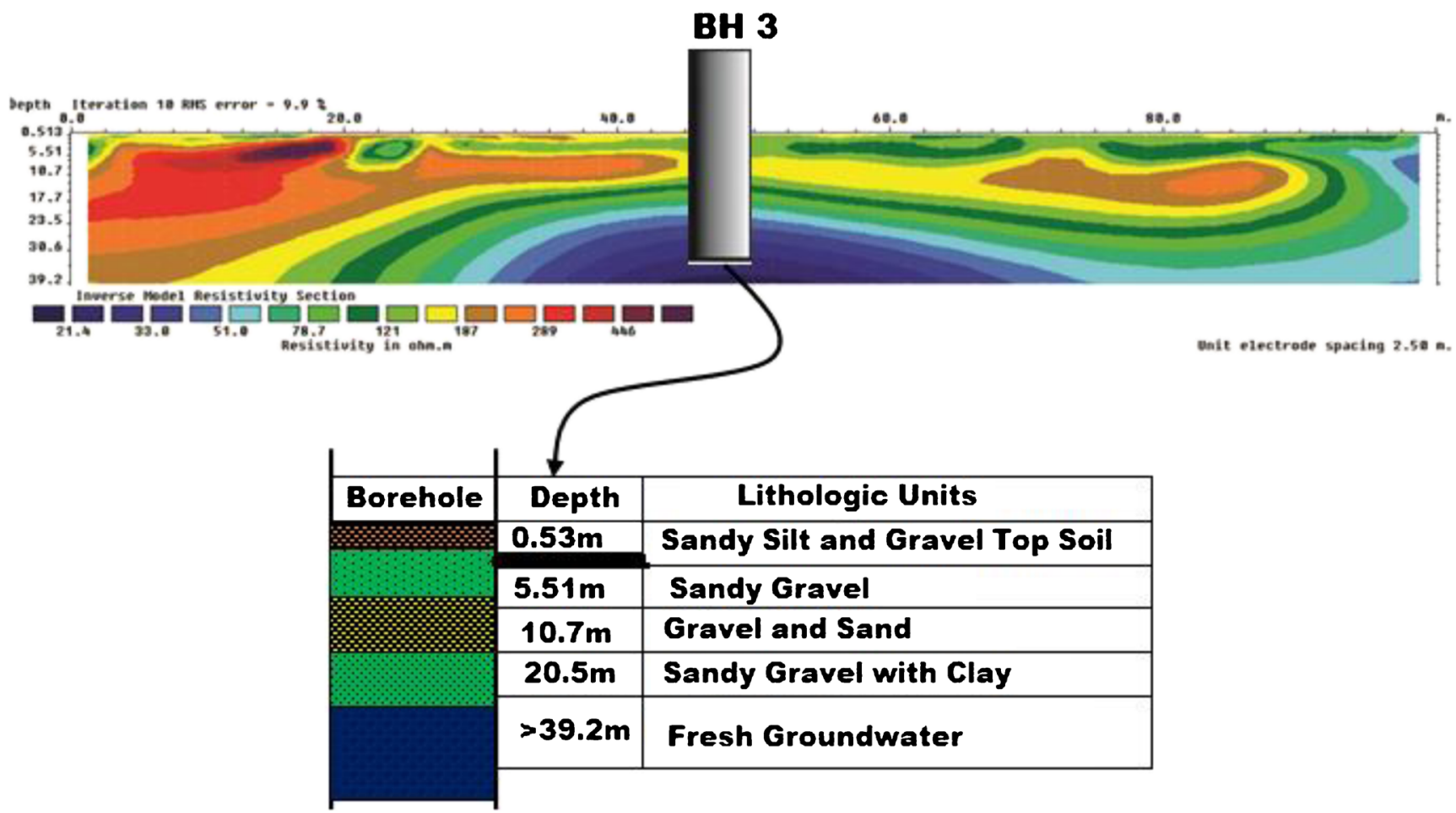

Fig. 72 D electrical resistivity tomography inversion model of the study area along profile 3 showing the location of borehole 3 at $50 \mathrm{~m}$

along with profile 2 . The topsoil was delineated at $5.51 \mathrm{~m}$ depth and correlated with gray silt, gravel, and sand layer of the borehole as shown. This layer has overlain the sandy gravel of approximately $5.19 \mathrm{~m}$ thickness. Granitic boulder was delineated at a very shallow depth of about $5.51 \mathrm{~m}$ between the starting point and about $20 \mathrm{~m}$ along the profile line.

Figure 7 shows resistivity profile 3 of the study area and was interpreted as shown in the lithologic section and borehole data. The shallowest topsoil layer was delineated at a depth of about $0.53 \mathrm{~m}$ which composed of sandy silt and gravel. The second subsurface structural layer was delineated as sandy gravel of about $6 \mathrm{~m}$ thickness. The layer underneath this unit was delineated as gravel and at a depth of about $10.7 \mathrm{~m}$ with sandy gravel and a clayey layer of about $20.5 \mathrm{~m}$ depth closely followed. It was carefully observed that the size of the units obtained from the borehole log along with this profile helps in the lithological classifications using the universal standard resistivity of subsurface materials.

Profile 4, as presented in Fig. 8, demonstrated the shallowest aquifer layer unit delineated at a depth of about

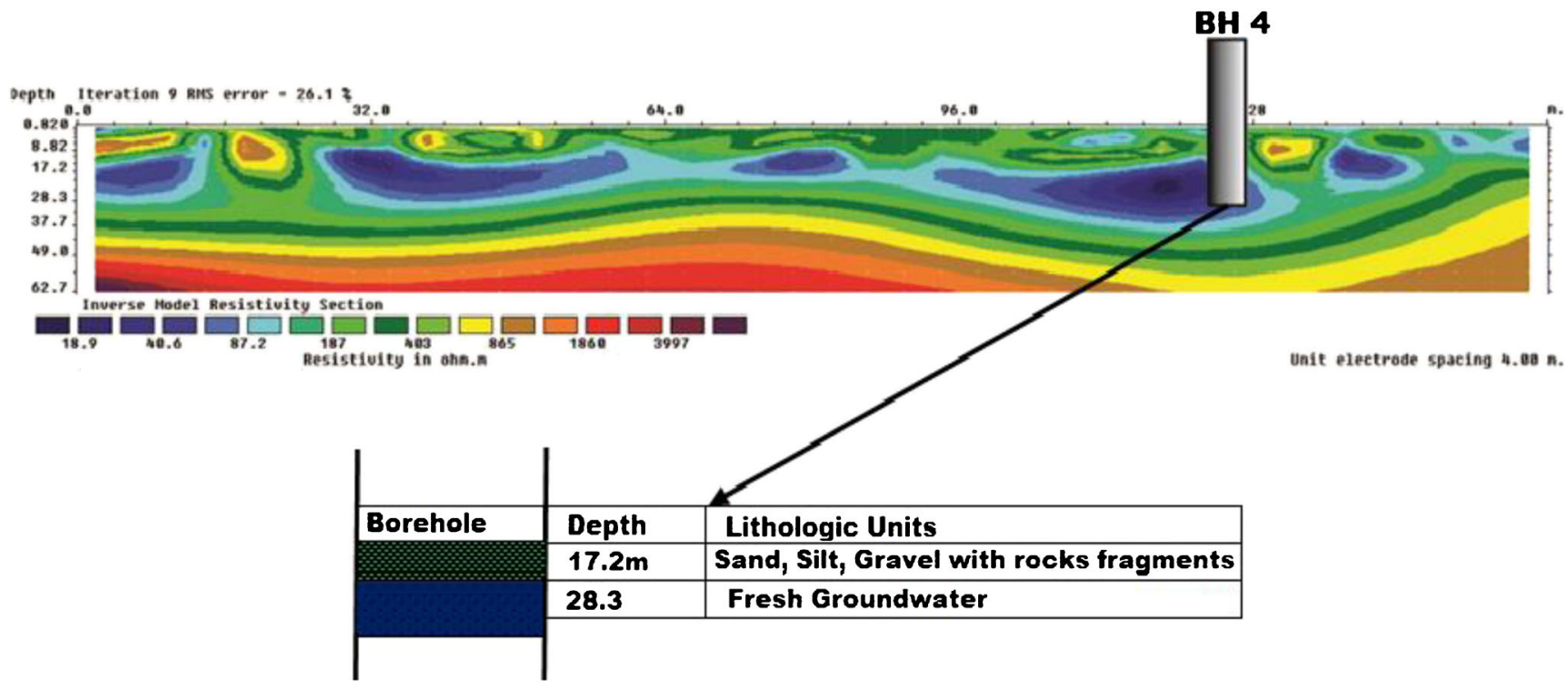

Fig. 8 2D electrical resistivity tomography inversion model of the study area along profile 4 showing the location of borehole 4 at $125 \mathrm{~m}$ 


\section{BH 5}

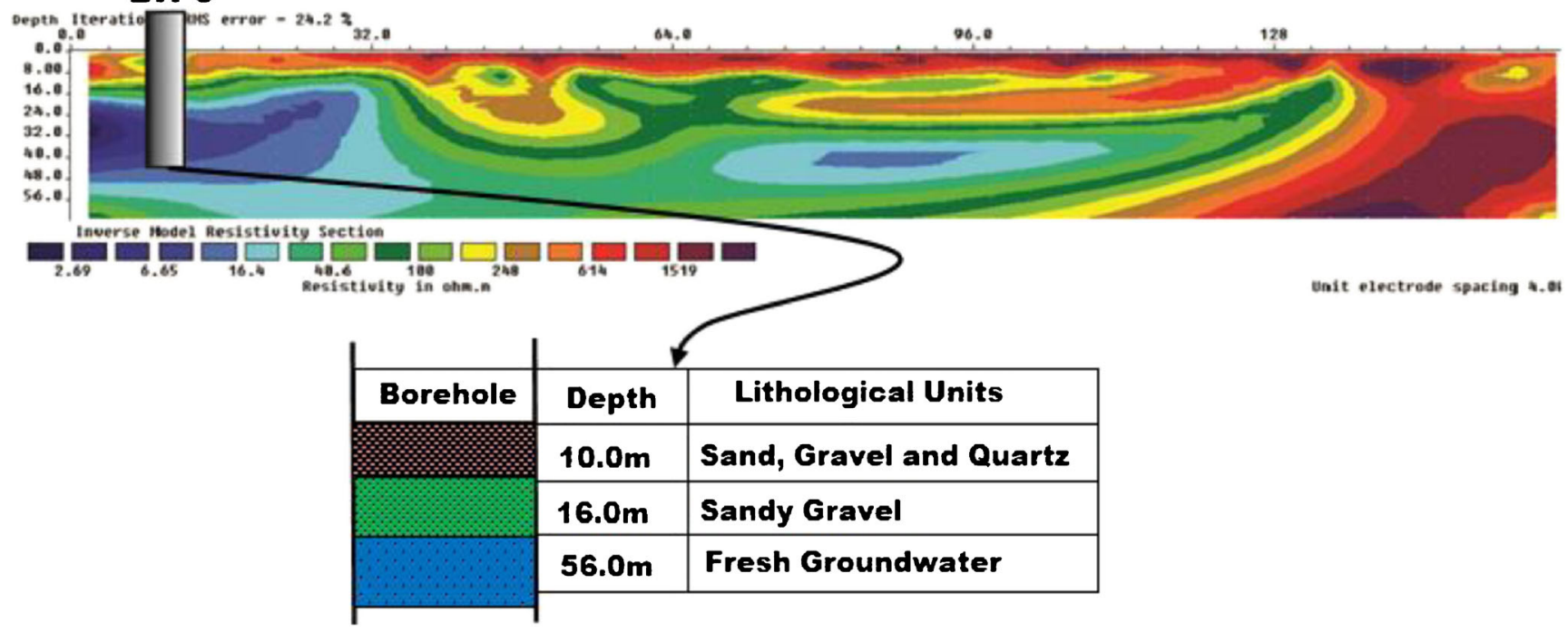

Fig. 9 2D electrical resistivity tomography inversion model of the study area along profile 5 showing the location of borehole 5 at $10 \mathrm{~m}$

$28.3 \mathrm{~m}$, at about $120 \mathrm{~m}$ along the surveyed line with a topsoil of $17.2 \mathrm{~m}$ thickness that comprises sand, silt, gravel, and mixtures of rock fragments.

Profile 5 showed in Fig. 9, with a $10 \mathrm{~m}$ thickness of topsoil unit that comprises sand, gravel, and quartzite. The second subsurface structural layer as delineated from borehole log was made up of sandy gravel delineated at about $16 \mathrm{~m}$ depth.

The interpreted subsurface geological units from borehole $\log$ and Res 2D inversion are shown in Fig. 10, along with profile 6 of the surveyed area. The topsoil was delineated at about $12 \mathrm{~m}$ depth and correlates with the gravel, sand, and granitic rock fragment layer of the borehole. The resistivity values obtained at this point varied from about $1800 \Omega$-m and above. This layer overlays the silt and sandy gravel at a depth of about $30 \mathrm{~m}$. Granitic boulder was delineated at a very shallow depth of about $6 \mathrm{~m}$ between the starting point and at a distance of about 6-39 $\mathrm{m}$ along the surveyed line.
Profile 7 as presented in Fig. 11 showed a very shallow aquifer layer at a depth of about $18 \mathrm{~m}$ between 90 and $120 \mathrm{~m}$ on the surface of the surveyed line. The topsoil along this surveyed line was delineated at about $17.7 \mathrm{~m}$ thickness that comprises sand, clay, and gravel.

Figure 12, along profile 8 of the surveyed area, shows that gravel, quartzite, and sandstone topsoil layer overlay the aquifer unit along this profile. The depth to the aquifer was delineated from the borehole $\log$ at about $30 \mathrm{~m}$ with moderately low resistivity values of between about $80 \Omega$-m and $120 \Omega$-m. The lateral spread of the unconfined aquifer unit along this line was at about $70-150 \mathrm{~m}$.

\section{The depth of the aquifer units}

Soaring water table in an area of intense precipitation such as we have on the east coast Peninsula Malaysia affects

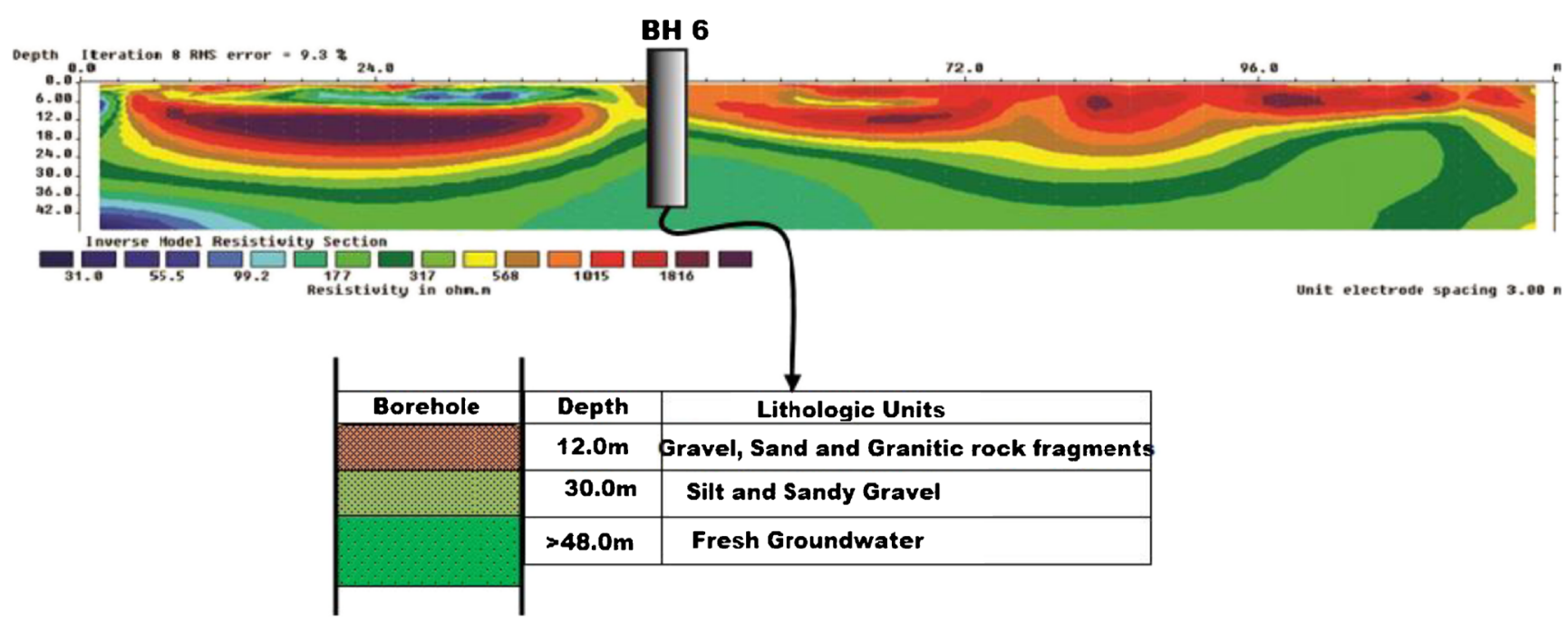

Fig. 10 2D electrical resistivity tomography inversion model of the study area along profile 6 showing the location of borehole 6 at $48 \mathrm{~m}$ 
BH 7

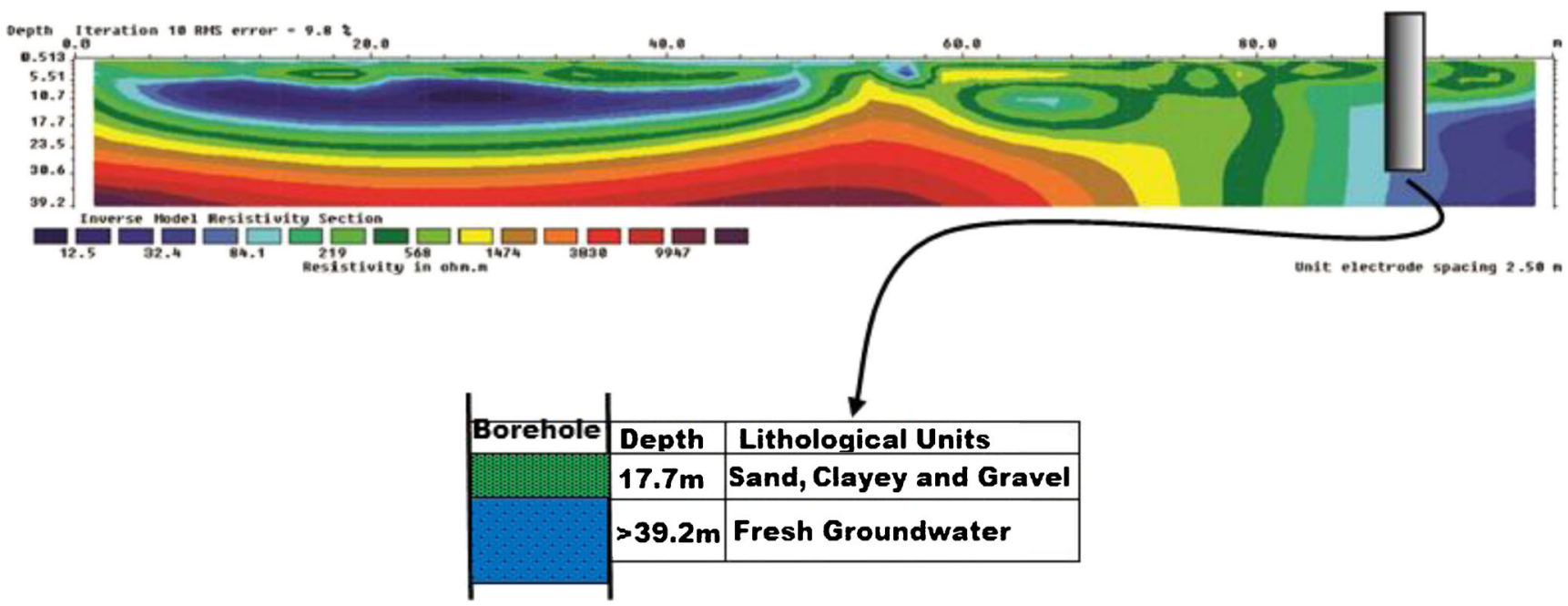

Fig. 11 2D electrical resistivity tomography inversion model of the study area along profile 7 showing the location of borehole 7 at $90 \mathrm{~m}$

permeation capability of the subsurface structures. This process takes place when the subsurface units get saturated quickly with intense rain than what the overflow volume can accommodate due to the porous nature of the aquifer units as shown from the borehole logs and the ERT profiles. Most of the aquifer units are unconfined and are opened to surface water. Figure 13 gives the extraordinary depth to the aquifer units which is a function of the water table level of the Kelantan River Basin. Depths ranged between about less than $5 \mathrm{~m}$ and about $145 \mathrm{~m}$ that was delineated with shallower regions in NW-SE direction. Moderately shallow depths were recorded along the southern part, but the NE direction has progressively increased in the depth from the central part. Given the highest elevations of the static water levels, as measured in the borehole, the depth to the water table map (Fig. 13) was prepared using the eight boreholes available for the study and overlaid on both the geology and the Topographical maps. Areas underlay by very shallow depth, i.e., (0-20 m) groundwater table was considered as most vulnerable to flooding which easily permits transmissivity between the surface water and groundwater in the area as shown by the green color along the Kelantan River Basin. The vulnerable areas occupied about $75 \%$ of the study area, but areas deeper than $20 \mathrm{~m}$ were considered as the least vulnerable to flooding which constitutes just about $25 \%$ denoted by the yellow to red colors as shown in Fig. 14. These are places denoted as high topography zones shown in Fig. 15.

\section{Weathered depth map}

Figure 14 illustrates the distribution of the weathered depth map or overburden thickness/depth to the bedrock within the study area which ranged between about a minimum of $100 \mathrm{~m}$ and a maximum of about $120 \mathrm{~m}$. The weathered material from the bedrock is a critical unit in the control of the flow of water in this area. It was observed that the southern part

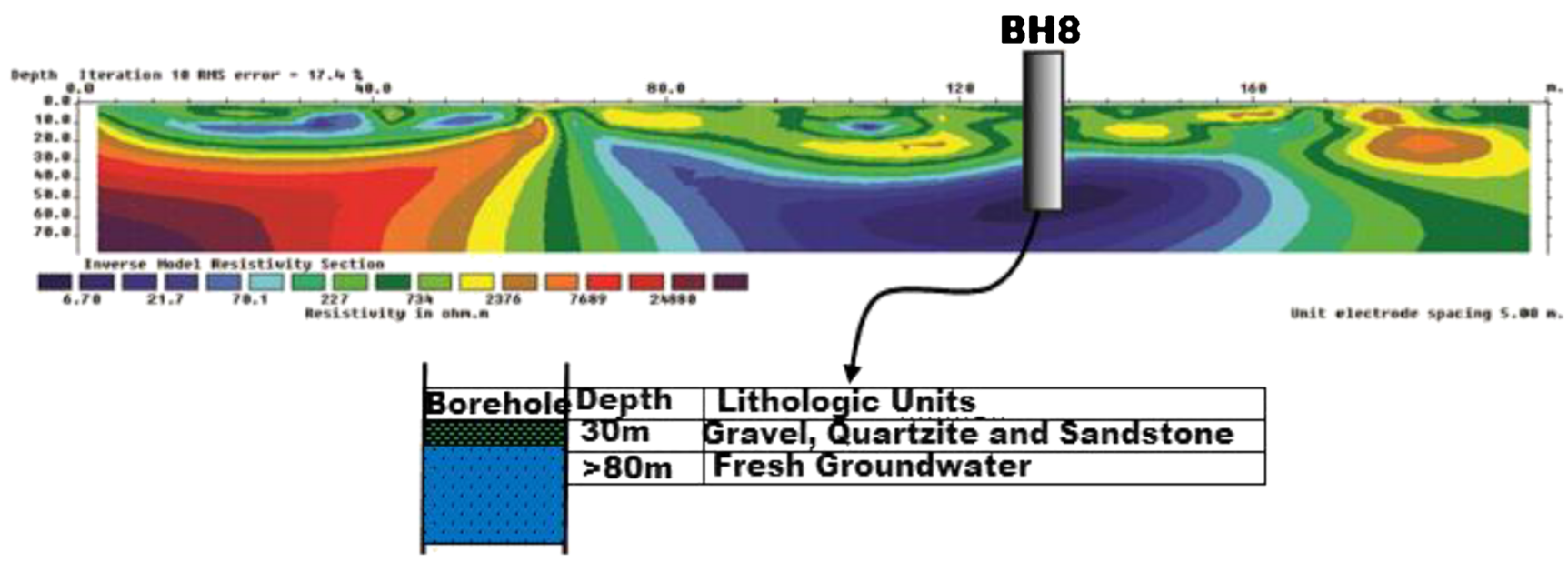

Fig. 12 2D electrical resistivity tomography inversion model of the study area along profile 8 showing the location of borehole 8 at $130 \mathrm{~m}$ 


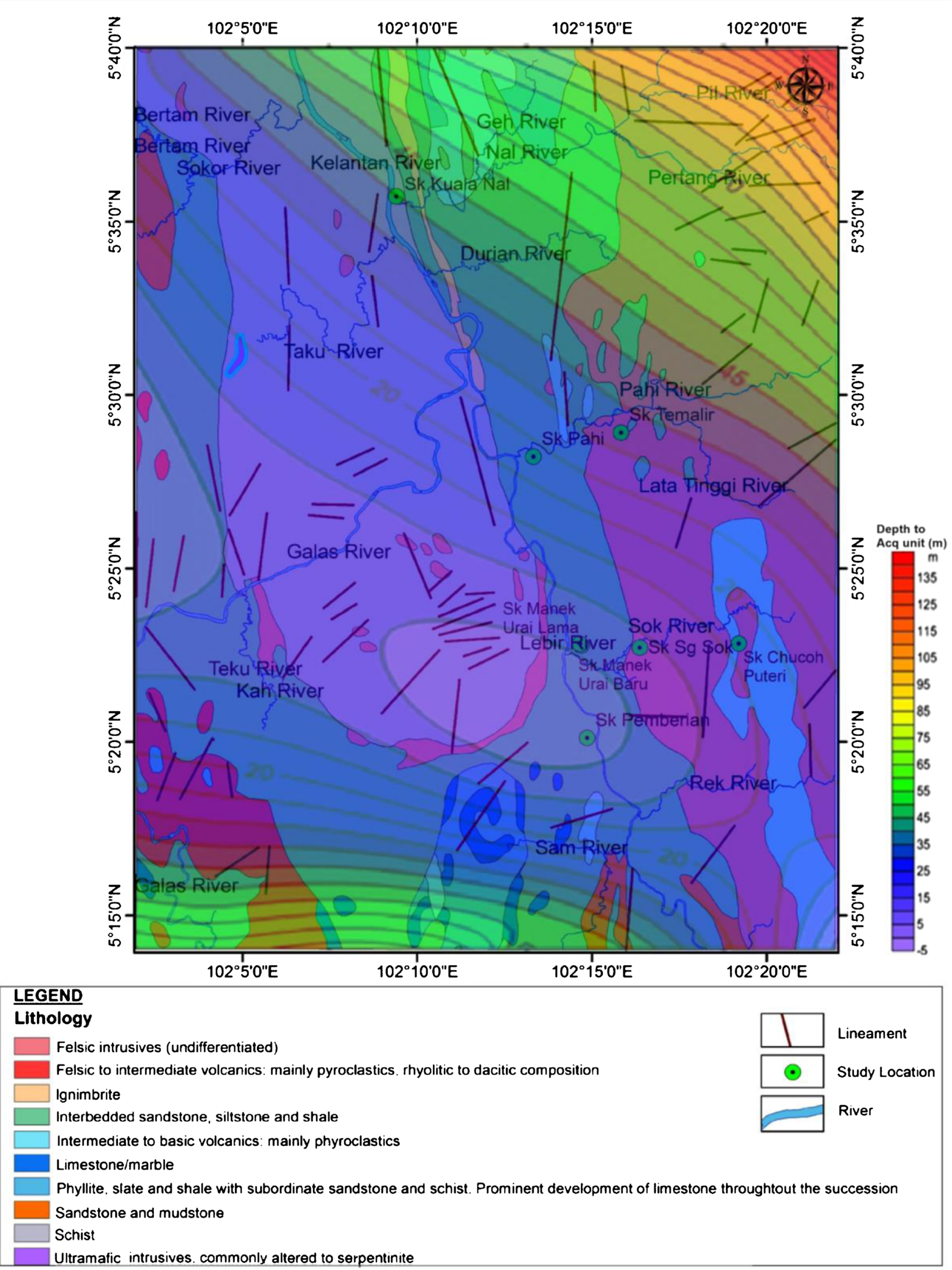

Fig. 13 Modeled depths to the aquifer units of the study area overlaid on the geology and topographical maps 


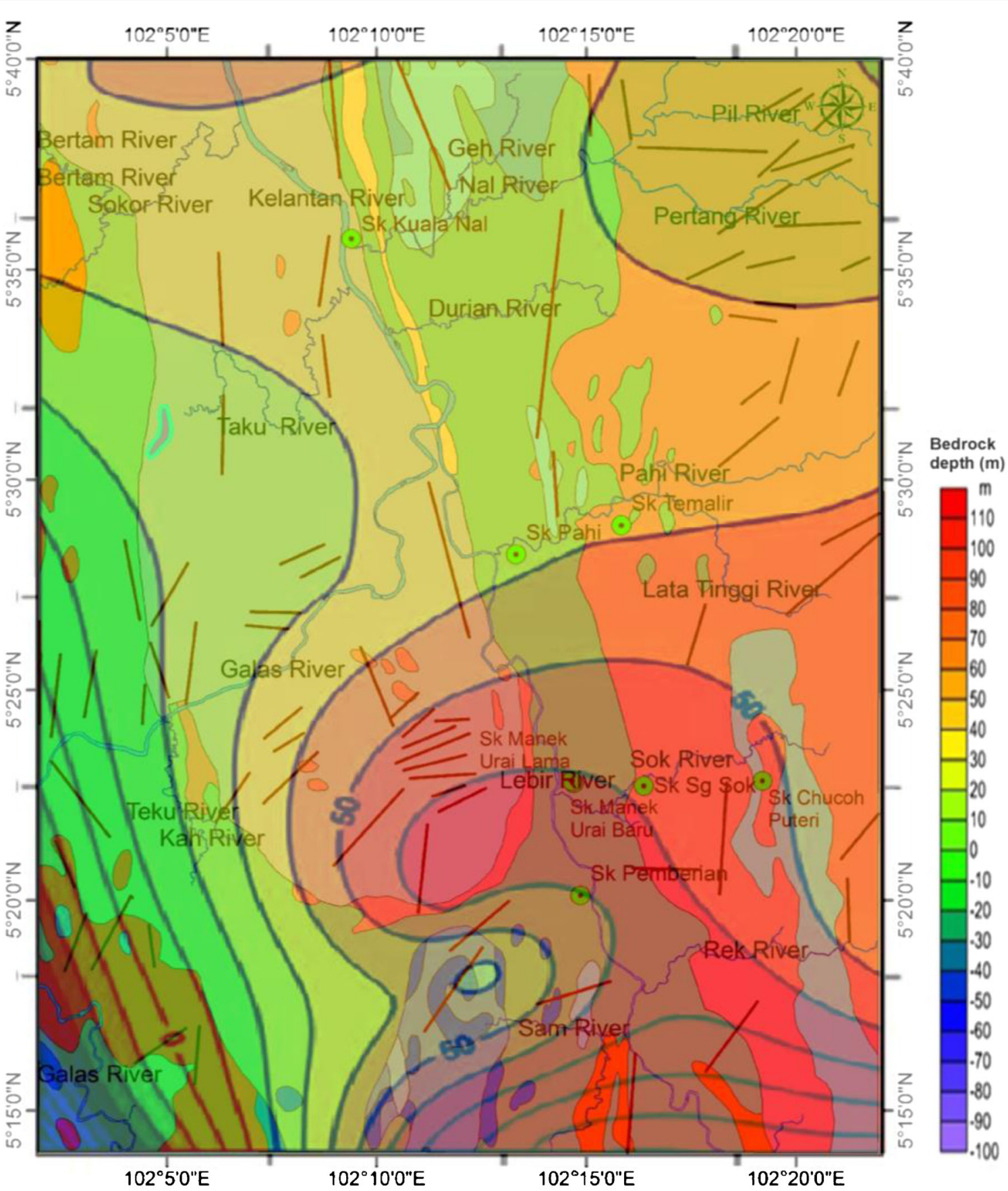

\section{LEGEND \\ Lithology}

Felsic intrusives (undifferentiated)

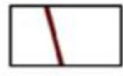

Lineament

Felsic to intermediate volcanics mainly pyroclastics, rhyolitic to dacitic composition Ignimbrite

Interbedded sandstone. siltstone and shale

Intermediate to basic volcanics: mainly phyroclastics

Study Location

Limestone/marble

Phyllite, slate and shale with subordinate sandstone and schist. Prominent development of limestone throughtout the succession

Sandstone and mudstone

Schist

Ultramafic intrusives commonly altered to serpentinite

Fig. 14 Modeled depths to the bedrock in the study area overlaid on the geology and topographical maps 


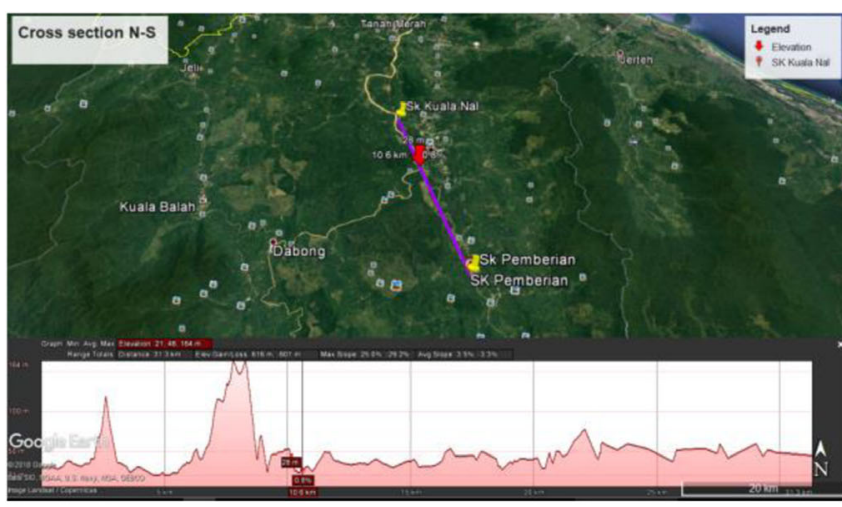

a

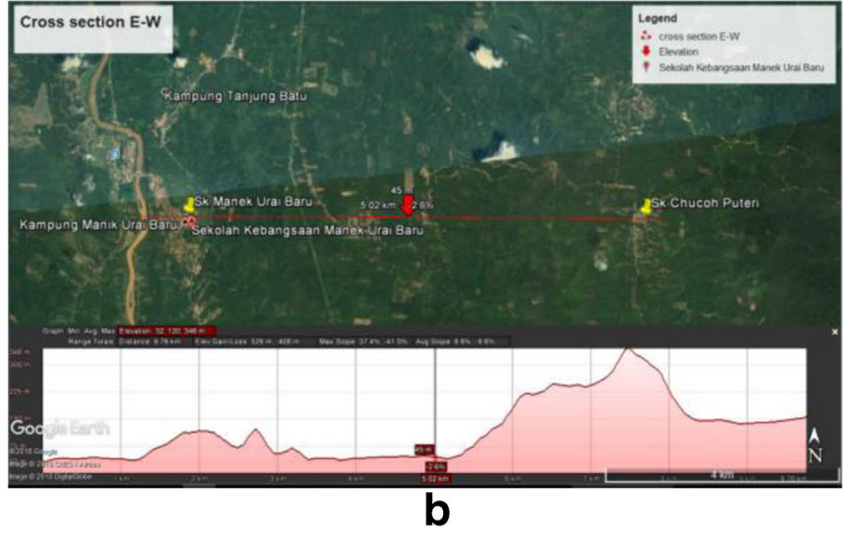

Fig. 15 Map of the study area showing the variations of the topography across the study locations: a N-S and b E-W, cross-sections

through to the south-eastern part constitutes areas with considerably thick overburden with values greater than $40 \mathrm{~m}$. The study area is overlain by fairly thin overburden from halfway of the southern part towards the south-western part through to the northern part where the overburden thicknesses recorded far less than $1.0 \mathrm{~m}$. Consequent upon this, the flow pattern of River Kelantan and its tributaries could be inferred that has been structurally and tectonically controlled as it caused significant degradation and transportation of the whole weathered materials from this area along its course. However, the fortification essential by a very thick weathered layer of the overburden unit is a function of both the chemical properties of the bedrock and the presence of dissolved minerals. From the borehole and ERT data, together with the outcrop mapping during the field survey, the interface between the topsoil wrap and the underlain weathered and fractured bedrock, which comprises moldy with fragmented rocks, is very inadequate, otherwise completely not in existence across this area. The partial coverage of the alteration zone that is completely nonexistent should have provided the needed essential storage and transmissivity if present in the east coast Peninsula Malaysia environments. Where we have this emplacement, it should impede groundwater-surface water inflow across the place and also interactions with the River Kelantan water and its tributaries, thereby prevents the effect of floods plausibly.

Table 1 Summary of the topography parameters obtained in the study area from Fig. 15

\begin{tabular}{llll}
\hline Slope $\%$ & & N-S cross-section & E-W cross-section \\
& Max & 25.0 & 37.4 \\
& Ave & 3.5 & 8.2 \\
& Min & -29.2 & -41.0 \\
\hline Elevation $(\mathrm{m})$ & Max & 164.0 & 348.0 \\
& Ave & 48.0 & 120.0 \\
& Min & 21.0 & 32.0 \\
\multicolumn{2}{l}{ Total distance $(\mathrm{km})$} & 31.3 & 10.0 \\
\hline
\end{tabular}

\section{The GOD-FBRT Index method}

This study followed the original rating scheme by Aller et al. (1987). GOD score parameters range 7-10. However, we modified the rating method with the additions of fluctuations of borehole water heights (FBWH) and the river bank heights $(\mathrm{RBH})$ together with the topography to produce GOD-FBRT Index to better refine the method by accounting for the literal movement of fluids within the subsurface. Four classes of vulnerability can be defined, i.e., low, medium, high, and very high. To evaluate the vulnerability of aquifers within the study area, we created the five parameters on:

Groundwater occurrence, Overall aquifer, Depth of water table, Fluctuations of Borehole water heights, and the Riverbank heights plus the Topography.

The groundwater occurrence is a function of the thickness of the regolith or vadose zone which is a characteristic of the inflow of water from the ground surface to the saturated zone, or aquifer.

The overall aquifer is defined by the presence or none presence of impermeable subsurface structures that give rise to the depth of water table.

Fluctuations of borehole water heights are a function of the amount of surface water infiltrate or seeps into the aquifer or saturated zone. The level of water in a borehole depends on the effective infiltration or subsurface lithologic. The topography of a place greatly affects the borehole water level that also varied with seasons.

Table 2 GOD-FBRT method for evaluating the degree of vulnerability and the corresponding index

\begin{tabular}{llllll}
\hline Vulnerability & Degree & Low & Medium & High & Very high \\
& Index & $0.1-0.2$ & $0.2-0.5$ & $0.5-0.7$ & $0.7-1.0$ \\
\hline
\end{tabular}


Table 3 Vulnerability score for the groundwater table

\begin{tabular}{lllll}
\hline Depth to groundwater table (m) & $0-15$ & $15-30$ & $30-45$ & $>45$ \\
Score & 10 & 9 & 8 & 7 \\
\hline
\end{tabular}

Fluctuations of the riverbank heights are a characteristic of intense precipitation within a given time and space. The amount of runoff is principally controlled by the topography.

Approximate even topography, as we have in the study area (Fig. 15), slows down the rate of runoff in the area, thus increases the chance of floods as the subsurface gets saturated, which ultimately increases vulnerability to flooding during intense precipitation. Table 1 gives the summary of the topography parameters recorded along the E-W and N-S cross-section. There is no significant change in the slope when the individual profile was considered as the area is almost flat with the exemption of granitic boulders observed in isolated places.

The aquifers in the study area are generally shallow with overburden layers that entirely consist of unconsolidated materials as shown in the borehole lithologies. The size of the constituents' grains that made up of these subsurface materials is of prime importance to the groundwater vulnerability during flooding. In the previous studies (i.e., Aller et al. 1987; Bai et al. 2012; Fernández-Martínez et al. 2017), who applied DRASTIC method wherein the aquifer and the vadose zones were well-thought-out as two separate zones, the present method considered these as one zone. In the present study area, the shallow groundwater surface as delineated combines with seasonal fluctuations in the groundwater level, and the same composition of the lithology across the area allowed the combinations of these zones as one.

With a very thin regolith envelop delineated by the ERT in this area, the almost near flat topography (Fig. 15a), recorded for this part of the Malaysian Peninsula, makes the subsurface structures susceptible to the inflow of surface water during intense precipitation, and hence highly vulnerable to flooding as shown in Fig. 15. The near flat topography has a great effect on the water invasion in this area. In addition to this, the shallow aquifers in the area are generally porous which permit water infiltration during the intense precipitation. Figure 15 correlates well with the bedrock depth delineated by the ERT as presented in Fig. 14.

The results from all the parameters considered (i.e., Tables 2, 3, 4, 5, and 6), for the vulnerability of the

Table 4 Vulnerability score for the borehole water heights

\begin{tabular}{lllll}
\hline Borehole water heights BH (m) & $0-20$ & $20-30$ & $30-40$ & $>40$ \\
Score & 10 & 9 & 8 & 7 \\
\hline
\end{tabular}

Table 5 Vulnerability score for the river bank water heights

\begin{tabular}{lllll}
\hline River bank heights RBH (m) & $0-10$ & $10-20$ & $20-30$ & $>30$ \\
Score & 7 & 8 & 9 & 10 \\
\hline
\end{tabular}

aquifer units of east coast Peninsula Malaysia, yield high to very high aquifer vulnerability scores of $8-10$ since the aquifers in the study area are generally shallow with nearly flat topography.

Four classes of vulnerability scores for the groundwater table are recorded as presented in Table 3.

Most places in the area scored between 8 and 10 as obtained in Fig. 13. The few less vulnerable zones scored 7.

The borehole water heights (BWH) and vulnerability scores are as presented in Table 4. In all the eight borehole data available for this study, borehole No 8 has BWH $>40 \mathrm{~m}$ which makes it less vulnerable. The other boreholes scored between 8 and 10 and are more susceptible to floods.

Table 5 shows the riverbank water height vulnerability scores. The parameters used for the scores were obtained from Fig. 4a. The results from the Malaysian Department of Irrigation and Drainage data on the RBWH during the Kelantan River basin floods helped in this regard. The River Kelantan and its tributaries overshot the warning level as recorded which eventually leads to flooding. The vulnerability scores showed that high and very high, (i.e., 9-10) were recorded for all the rivers in the area as water heights recorded were $>20 \mathrm{~m}$.

The topography of the study area is nearly flat which make runoff after intense precipitation to be very slow as the water flows towards the sea. The vulnerability scores are shown in Table 6 as generated in Fig. 15. The percentage recorded gives high to very high vulnerable zones in almost all the areas with few exceptions where the percentage obtained is quite higher, i.e., $>30 \%$.

The overall vulnerability index map with the application of the enhanced GOD method as GOD-FBRT method is as shown in Fig. 16. Table 2 is used to standardize the values (i.e., $0-1)$. These values correspond to the range of the degree of vulnerability computed in the study area. The applications of the derived GOD method (i.e., GOD-FBRT) are capable to present the subsurface structures of the east coast Peninsula Malaysia as high to very high vulnerable with few exceptional areas where there is less vulnerability. Areas with greater depth of groundwater level (i.e., $>40 \mathrm{~m}$ ) showed low vulnerability.

Table 6 Vulnerability score for the topography parameters

\begin{tabular}{lllll}
\hline Topography parameter (\%) & $0-10$ & $10-20$ & $20-30$ & $>30$ \\
Score & 10 & 9 & 8 & 7 \\
\hline
\end{tabular}




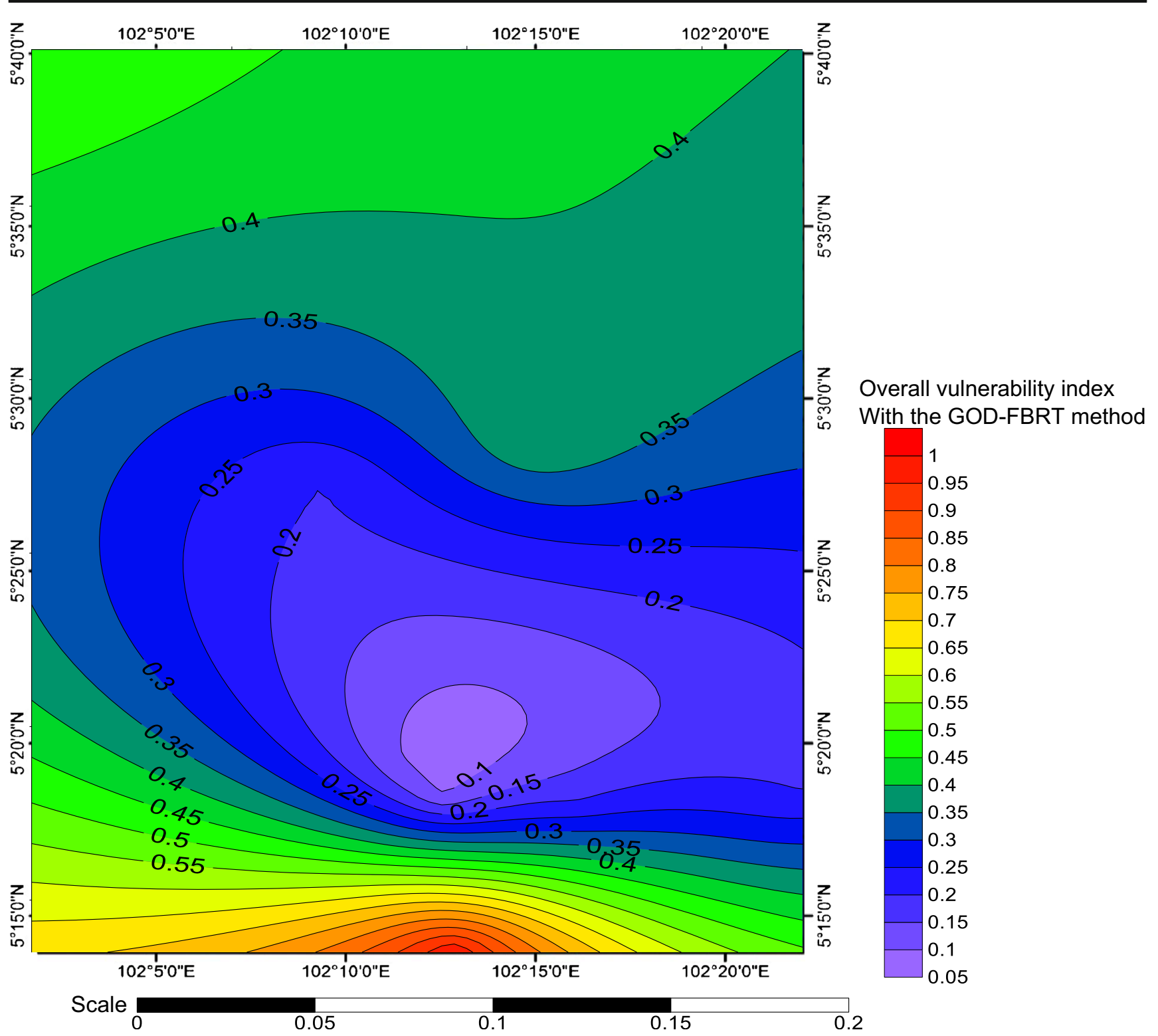

Fig. 16 Overall vulnerability index map with the applications of GOD-FBRT method

\section{Conclusion}

This study could show the alteration zone, which should have provided the necessary storage and transmissivity that would hinder ground-surface water inflow, and also interactions with the River Kelantan water and perhaps prevents the consequence of flooding, is essentially lacking in the area surveyed. The application of surface geophysical methods utilizing ERT combined with the borehole lithologic logs units together with surface geological mapping has contributed to better the understanding of the existing connection between the subsurface groundwater and flooding in the east coast Peninsula Malaysia. This study has also confirmed the reason for the bad condition of groundwater in this part of the country. In the present paper, we amplify the interactions between surface water and subsurface water transmissivity during intense precipitation, which play an important role in the devastating floods ravaging the communities almost on a yearly basis and concludes that an average of $75 \%$ of this area is vulnerable to floods.

Furthermore, the study showed from the borehole and ERT data and the outcrop mapping during the field survey, the flow pattern of the rivers in the area as being structurally and tectonically control with the subsurface units getting drenched rapidly with extreme rains periods than what the overflow volume can accommodate due to the topographic condition. On this wise, the infiltration capability of the subsurface structures in this area is greatly affected by the rising water table during these periods of intense Southeast Asian winter monsoon season usually culminates with severe precipitation as shown in the study. 
This study was able to provide good complementary results from the 2D electrical resistivity tomography, ERT surveys, the rainfall data, the borehole lithologic units, and the topography of the area, to study the vulnerability. The refined GODFBRT Index method implemented in this study made the approach adopted to be the best in correlation for mapping deeply weathered shallow bedrock units prone to floods. The bedrock depth map generated in Fig. 16 reflects the pattern of flow of the River Kelantan and the Topography recorded in Fig. 15. The configuration of the Kelantan River basin land system as delineated by this study makes the entire east coast areas vulnerable to flooding. Vulnerability in this area is severe due to the topographic nature that impedes runoff after intense precipitation together with the lithological nature of the subsurface strata. Adequate measures need to be put in place for the groundwater protection in the region judging by the porous nature of the aquifers.

Acknowledgments The authors are most grateful to the two universities that supported this work, i.e., Universiti Sains Malaysia, Pinang, and Universiti Kebangsaan Malaysia, Bangi, Selangor. We also appreciate the people that worked with us during and after the field data collection and interpretation as well as the reviewers who helped to reshape the paper.

Open Access This article is distributed under the terms of the Creative Commons Attribution 4.0 International License (http:// creativecommons.org/licenses/by/4.0/), which permits unrestricted use, distribution, and reproduction in any medium, provided you give appropriate credit to the original author(s) and the source, provide a link to the Creative Commons license, and indicate if changes were made.

\section{References}

Alexander J (1968) Geology and mineral resources of the Bentong area, Pahang. Mem Geol Surv West Malaysia 8:250

Aller L, Bennett T, Lehr J, Petty R, Hackett G (1987) DRASTIC-A standardized system for evaluating ground water pollution potential using hydrogeologic settings: Ada, Okla., Robert S. KenEnvironmental Research Laboratory. EPA/600/2-87-035, volumes 1 and 2

Allison HE, Hobbs RJ (2004) Resilience, adaptive capacity, and the lockin trap of the Western Australian agricultural region. Ecol Soc 9

Altinakar MS, Mcgrath MZ, Ozeren Y, Omari H (2008) Modeling and risk analysis for floods due to failure of water control infrastructures. Proceedings (CD-ROM) of the International Symposium on Uncertainties in Hydrologic and Hydraulic Modeling

Bai L, Wang Y, Meng F (2012) Application of DRASTIC and extension theory in the groundwater vulnerability evaluation. Water Environ J 26:381-391

Baksi AK, Barman T, Paul D, Farrar E (1987) Widespread early cretaceous flood basalt volcanism in eastern India: geochemical data from the Rajmahal-Bengal-Sylhet traps. Chem Geol 63:133-141

Bayley PB (1995) Understanding large river: floodplain ecosystems. BioScience 45:153-158

Benson AK, Payne KL, Stubben MA (1997) Mapping groundwater contamination using dc resistivity and VLF geophysical methods-a case study. Geophysics 62:80-86
Chambers JE, Kuras O, Meldrum PI, Ogilvy RD, Hollands J (2006) Electrical resistivity tomography applied to geologic, hydrogeologic, and engineering investigations at a former wastedisposal site. Geophysics 71:B231-B239

Civita M, De Maio M (1997) SINTACS: Un sistema parametrico per la valutazione e la cartografia delle vulnerabilità degli acquiferi all'inquinamento. Metodologia e automatizzazione. Pitagora Editrice

Dahan O, Tatarsky B, Enzel Y, Kulls C, Seely M, Benito G (2008) Dynamics of flood water infiltration and ground water recharge in hyperarid desert. Groundwater 46:450-461

Dawod GM, Mirza MN, Al-Ghamdi KA (2012) GIS-based estimation of flood hazard impacts on road network in Makkah city, Saudi Arabia. Environ Earth Sci 67:2205-2215

Feng C, Wang YC (2011) GIScience research challenges for emergency management in Southeast Asia. Nat Hazards 59:597-616

Fernández-Martínez JL, Xu S, Sirieix C, Fernández-Muniz Z, Riss J (2017) Uncertainty analysis and probabilistic segmentation of electrical resistivity images: the $2 \mathrm{~d}$ inverse problem. Geophys Prospect $65: 112-130$

Foster S (1987) Fundamental concepts in aquifer vulnerability, pollution risk and protection strategy: international conference, 1987, Noordwijk Aan zee, the Netherlands vulnerability of soil and groundwater to pollutants the Hague, Netherlands Organization for Applied Scientific Research, Netherlands Organization for Applied Scientific Research

Giustarini L, Hostache R, Matgen P, Schumann G-P, Bates PD, Mason DC (2013) A change detection approach to flood mapping in urban areas using TerraSAR-X. Geosc RemoteSensing IEEE Transactions on $51: 2417-2430$

Ibbitt R, Takara K, Mohd. Nor Bin Mohd. Desa \& Pawitan, H (Ed) (2002) Kelantan River Catalogue of Rivers for Southeast Asia and the Pacific. The UNESCO-IHP Regional Steering Committee for Southeast Asia and the Pacific, UNESCO-IHP Publication

Juneng L, Tangang FT (2008) Level and source of predictability of seasonal rainfall anomalies in Malaysia using canonical correlation analysis. Int J Climatol 28:1255-1267

Juneng L, Tangang FT, Kang H, Lee W-J, Seng YK (2010) Statistical downscaling forecasts for winter monsoon precipitation in Malaysia using multimodel output variables. J Clim 23:17-27

Khoo TT (1980) Some comments on the emplacement level of the Kemahang granite, Kelantan. In: Teh GH (ed) Geological Society of Malaysia. Geological Society of Malaysia, Kuala Lumpur, pp 93 102

Khoo T, Tan B (1983) Geological evolution of peninsular Malaysia. Workshop on stratigraphic correlation of Thailand and Malaysia. 253-290

Loke MH (2014) 2-day workshop on 2D and 3D electrical Resisitivity imaging surveys. Universiti Sains Malaysia, Penang

Loke M, Chambers J, Ogilvy R (2006) Inversion of 2D spectral induced polarization imaging data. Geophys Prospect 54:287-301

Malehmir A, Socco LV, Bastani M, Krawczyk CM, Pfaffhuber AA, Miller RD, Maurer H, Frauenfelder R, Suto K, Bazin S (2016) Near-surface geophysical characterization of areas prone to natural hazards: a review of the current and perspective on the future. Advances in Geophysics. Elsevier, Amsterdam

Meyer V, Scheuer S, Haase D (2009) A multicriteria approach for flood risk mapping exemplified at the Mulde river, Germany. Nat Hazards 48:17-39

MMD (2015) The 2014-15 Malaysia floods. MET. Ministry of Science and Technology Innovation (MOSTI), Kuala Lumpur

Oldenborger GA, Routh PS, Knoll MD (2005) Sensitivity of electrical resistivity tomography data to electrode position errors. Geophys J Int 163:1-9

Park S, Choi C, Kim B, Kim J (2013) Landslide susceptibility mapping using frequency ratio, analytic hierarchy process, logistic regression, 
and artificial neural network methods at the Inje area, Korea. Environ Earth Sci 68:443-1464

Pelling M (1997) What determines vulnerability to floods; a case study in Georgetown, Guyana. Environ Urban 9:203-226

Reynolds JM (1997) An introduction to applied and environmental geophysics. John Wiley and Sons, Chichester

Richardson JA (2013) The geology and mineral resources of the neighbourhood of Raub, Pahang, federated Malay states, with an account of the geology of the Raub Australian gold mine

Salimun E, Tangang F, Juneng L (2010) Simulation of heavy precipitation episode over eastern peninsular Malaysia using MM5: sensitivity to cumulus parameterization schemes. Meteorog Atmos Phys 107:3349

Tangang FT, Juneng L, Salimun E, Vinayachandran P, Seng YK, Reason C, Behera S, Yasunari T (2008) On the roles of the northeast cold surge, the Borneo vortex, the madden-Julian oscillation, and the
Indian Ocean dipole during the extreme 2006/2007 flood in southern peninsular Malaysia. Geophys Res Lett, 35

Tangang FT, Xia C, Qiao F, Juneng L, Shan F (2011) Seasonal circulations in the Malay peninsula eastern continental shelf from a wavetide-circulation coupled model. Ocean Dyn 61:1317-1328

Tehrany MS, Lee M-J, Pradhan B, Jebur MN, Lee S (2014) Flood susceptibility mapping using integrated bivariate and multivariate statistical models. Environ Earth Sci 72:1-15

Varikoden H, Preethi B, Samah A, Babu C (2011) Seasonal variation of rainfall characteristics in different intensity classes over peninsular Malaysia. J Hydrol 404:99-108

Williams J, Scheib A (2008) Application of near-surface geophysical data in GSI3D: case studies from Shelford and Talla Linnfoots

Wolters T, Koch M, Rahimian M (2014) Groundwater vulnerability assessment using a common index model adapted to urban conditions 